\title{
PLEASE STRATEGY FOR TEACHING WRITING VIEWED FROM STUDENTS' SELF-ESTEEM
}

\author{
Arief Eko Priyo Atmojo ${ }^{*}$ \\ 1 IAIN Surakarta, Indonesia \\ arief.atmojo93@iain-surakarta.ac.id
}

\begin{abstract}
This research aims to examine whether: (1) PLEASE strategy is more effective than RAFT strategy for writing; (2) Students having high self-esteem are better in writing than those having low self-esteem; and (3) There is an interaction between the strategies and the students' self-esteem. This research was done at a state secondary school located in Sragen, Jawa Tengah, Indonesia. Cluster random sampling was employed to get the sample consisting of two classes. PLEASE strategy was used in the experimental class meanwhile RAFT strategy was employed in the control class. The students in each class were categorized into students having high self-esteem and low self-esteem. Writing test and self-esteem questionnaire were utilized to gather data. Multifactor Analysis of Variance ANOVA 2 x 2 test and Tukey test were employed to analyze the data after normality and homogeneity tests were undergone. The results indicate that: (1) PLEASE strategy is more effective than RAFT strategy for writing; (2) Students having high self-esteem are better in writing than those having low self-esteem; and (3) There is an interaction between the strategies and the students' self-esteem. It suggests that PLEASE strategy is an effective strategy for writing compared to RAFT strategy. Further researches comparing PLEASE strategy to other strategies, techniques, or methods and collaborating it with media and innovative materials for writing are encouraged.
\end{abstract}

Keywords: PLEASE Strategy, RAFT Strategy, Self-Esteem, Teaching Writing Skill.

\section{INTRODUCTION}

Writing is needed in classroom activities and tasks (Guzel-Ozmen, 2009). Students' achievement in writing are important for their lifelong success. In fact, enhancing students' writing is a challenging task for teachers. Many publications related to writing suggest that further researches on instructional methods are still necessary. The existing literature cannot sufficiently provide the best teaching practices (Nielsen, 2012). Puteh, Rahamat, \& Karim (2010) argue that writing is a fundamental and essential skill to exhibit content knowledge. However, students experience many problems such as lack of ideas, difficulty to seek interesting topic, and inability to find words to use.

Rijlaarsdam, Bergh, \& Couzijn (2005) state that writing is difficult because it involves many interactive cognitive activities including content generation and organization, text organization and production, and revision. Flynn \& Stainthorp (2006) agree that writing 
requires simultaneous integration of many activities and gives great demands on the cognitive system. It is a challenging, difficult, complicated, and demanding process (Ka-kandee \& Kaur, 2015).

Writing is an interactive and complex activity relying on mental process of creating thoughts and considering the best way to put them through symbols which begins with making decisions on the amount and type of information, gradually continues to arrange the information, and ends up with the decisions of how all messages will be linguistically expressed to make an intelligible text aiming to share meanings and make impressions (Adler-Kassner \& O’Neill, 2010; Browne, 2007; Byrne, 1993; Hyland, 2009; Koutsoubou, 2005). Writing consists of five aspects namely mechanics, vocabulary, grammar or language use, content, and organization (Adler-Kassner \& O'Neill, 2010; Brown, 2001; Davison \& Dowson, 2002; Nation, 2009; Nik, Hamzah, \& Rafidee, 2010).

Self-esteem has an important role in writing. Positive self-esteem is useful to motivate the students to demonstrate their writing. Otherwise, students having low selfesteem experience many problems in writing (Khansir \& Abdolahi, 2014). Fahim \& Rad (2012) assert that some writing problems emerge from psychological aspects, especially self-esteem which has become a concern and had determining effects on language learning.

Self-esteem is someone's fundamental self-assessment of his competence in dealing with life challenges based on the incongruity between his self-concept and ideal self and his own worth to be happy which is influenced by some considerations of his aspirations and standards about life as well as the actions and reactions of other persons towards him (Branden, 1995; Caunt, 2003; Lawrence, 2006; Mruk, 2006; Plummer, 2005). Self-esteem consists of four aspects namely competence, confidence, worthiness, and acceptance (Branden, 1995; Greene, 2003; Lawrence, 2006; Plummer, 2005).

In this research, PLEASE strategy is employed in the experimental class. PLEASE strategy is a metacognitive strategy to cope with difficulties in writing process including prewriting planning, composition, and paragraph revision. It equips students with a set of behaviors by utilizing a first-letter mnemonic to remind each strategic step and guide them to accomplish a writing task independently (Milford \& Harrison, 2010; Welch, 1992). The steps of PLEASE strategy are stated as follows: (a) Pick a topic to be written; (b) List ideas related to the topic; (c) Evaluate the list to obtain relevant ideas; (d) Activate with topic sentences; (e) Supply supporting details to complement the topic sentences; and (f) End with a conclusion (Milford \& Harrison, 2010).

On the other hand, RAFT strategy is used in the control class. RAFT strategy is a creative writing strategy helping students through writing experience to understand their role as a writer, their audiences, the format of their writing, and the topic being addressed before they start writing. Every RAFT work is written from a viewpoint except that of the student, to audiences except the teacher, and in a format except the standard theme (Santa et al., 1988; Sejnost \& Thiese, 2010; Yerger, 2014). The steps of RAFT strategy are stated as follows: (a) Determine important ideas based on reading assignment to determine the topic; (b) Brainstorm the possibility of roles which the students can assume to determine their roles; (c) Determine the audiences; and (d) Decide the format of writing (Sejnost \& Thiese, 2010). 
Some previous researches (Akincilar, 2010; Fahim \& Rad, 2012; Khansir \& Abdolahi, 2014; Milford \& Harrison, 2010; Welch, 1992; Welch \& Jensen, 1990) have been reviewed to gain deeper insights on the effectiveness of PLEASE strategy for writing and the relationship between students' writing and their self-esteem. This present research differs from the previous researches. The difference is on the strategy used in the control class, the attributive variable employed, and the health condition of the sample. Therefore, this research aims to reveal whether: (1) PLEASE strategy is more effective than RAFT strategy for writing; (2) Students having high self-esteem are better in writing than those having low self-esteem; and (3) There is an interaction between the strategies and the students' selfesteem.

\section{METHODS}

This research was carried out at a state secondary school located in Sragen, Jawa Tengah, Indonesia. It employed a quasi-experimental design because the sample was two already existing classes selected by cluster random sampling. It used factorial design $2 \times 2$ with post-test only design (no pre-test). The sample was classified into an experimental class and a control class. Each class consisted of 26 students. PLEASE strategy was employed in the experimental class meanwhile RAFT strategy was used in the control class.

A writing test and a self-esteem questionnaire were administered to gather data. The writing test instruction was tried out first to check its readibility. The self-esteem questionnaire was also tried out to get valid items and ensure its reliability. It proved reliable since $r_{o}(0.89)$ was higher than $r_{t}(0.388)$. Normality test and homogeneity test had been done before the data were analyzed. The data are considered as in normal distribution if $\mathrm{L}_{0}$ is lower than $\mathrm{Lt}_{t}$ at the significance level $\alpha=0.05$. Moreover, the data are considered as homogeneous if $\chi_{0}{ }^{2}$ is lower than $\chi_{t^{2}}$ at the significance level $\alpha=0.05$. Descriptive and inferential statistics were then employed to analyze the data. Descriptive statistics were used to seek mean, median, mode, and standard deviation which ranged from 5.4 to 9.1. Further, inferential statistics were employed to test hypotheses. ANOVA $2 \times 2$ test and Tukey test were utilized here.

\section{RESULTS}

Having had been taught eight meetings each, both control and experimental classes were then given a writing test and requested to fill in a self-esteem questionnaire. The students' writing and self-esteem scores of both classes can be seen in table 1 and table 2 following sequentially below: 
Table 1. The Students' Writing and Self-Esteem Scores of Control Class

\begin{tabular}{|c|c|c|c|}
\hline No. & Name & Writing Score & Self-Esteem Score \\
\hline 1 & STUDENT C-A & 72 & 57.5 \\
\hline 2 & STUDENT C-B & 66 & 56.88 \\
\hline 3 & STUDENT C-C & 75 & 60 \\
\hline 4 & STUDENT C-D & 72 & 61.25 \\
\hline 5 & STUDENT C-E & 58 & 61.25 \\
\hline 6 & STUDENT C-F & 54 & 54.38 \\
\hline 7 & STUDENT C-G & 70 & 66.88 \\
\hline 8 & STUDENT C-H & 68 & 57.5 \\
\hline 9 & STUDENT C-I & 74 & 66.88 \\
\hline 10 & STUDENT C-J & 55 & 57.5 \\
\hline 11 & STUDENT C-K & 67 & 65.62 \\
\hline 12 & STUDENT C-L & 82 & 66.25 \\
\hline 13 & STUDENT C-M & 68 & 47.5 \\
\hline 14 & STUDENT C-N & 76 & 63.12 \\
\hline 15 & STUDENT C-O & 72 & 68.12 \\
\hline 16 & STUDENT C-P & 66 & 63.12 \\
\hline 17 & STUDENT C-Q & 80 & 67.5 \\
\hline 18 & STUDENT C-R & 59 & 59.38 \\
\hline 19 & STUDENT C-S & 62 & 61.88 \\
\hline 20 & STUDENT C-T & 70 & 56.88 \\
\hline 21 & STUDENT C-U & 63 & 64.38 \\
\hline 22 & STUDENT C-V & 73 & 58.75 \\
\hline 23 & STUDENT C-W & 78 & 59.38 \\
\hline 24 & STUDENT C-X & 71 & 56.88 \\
\hline 25 & STUDENT C-Y & 63 & 60.62 \\
\hline \multirow[t]{3}{*}{26} & STUDENT C-Z & 63 & 57.5 \\
\hline & TOTAL & 1777 & 1576.90 \\
\hline & MEAN & 68.35 & 60.65 \\
\hline
\end{tabular}

Table 2. The Students' Writing and Self-Esteem Scores of Experimental Class

\begin{tabular}{cccc}
\hline No. & Name & Writing Score & Self-Esteem Score \\
\hline 1 & STUDENT X-A & 71 & 58.12 \\
2 & STUDENT X-B & 86 & 68.75 \\
3 & STUDENT X-C & 82 & 62.50 \\
4 & STUDENT X-D & 66 & 58.75
\end{tabular}


9 STUDENT X-I

61.88

10 STUDENT X-J

11 STUDENT X-K

12 STUDENT X-L

13 STUDENT X-M

14 STUDENT X-N

74.38

15 STUDENT X-O

72

71.25

16 STUDENT X-P

69

62.50

17 STUDENT X-Q

63

51.25

18 STUDENT X-R

64

61.25

19 STUDENT X-S

74

60.62

20 STUDENT X-T

84

66.25

21 STUDENT X-U

75

71.88

22 STUDENT X-V

69

55.62

23 STUDENT X-W

55.62

24 STUDENT X-X

59

80.62

25 STUDENT X-Y

74

59.38

26 STUDENT X-Z

68.75

TOTAL

67

1649.35

72.88 63.44

ANOVA $2 \times 2$ test was later done to test the hypotheses. $\mathrm{H}_{0}$ is rejected if $\mathrm{F}_{\mathrm{o}}$ is higher than $\mathrm{F}_{\mathrm{t}}$ $\left(F_{0}>F_{t}\right)$ indicating that there is a significant difference. The computation results of ANOVA $2 \times 2$ test are shown in table 3 . In addition, the results of mean scores are presented in table 4.

Table 3. The Results of ANOVA (Multifactor Analysis of Variance) 2 × 2 Test

\begin{tabular}{|c|c|c|c|c|c|}
\hline Source of Variance & SS & $\mathrm{df}$ & MS & Fo & $\mathrm{Ft}(0.05)$ \\
\hline Between columns & 267.77 & 1 & 267.77 & 5.50 & 4.04 \\
\hline Between rows & 694.23 & 1 & 694.23 & 14.26 & \\
\hline Columns by rows (interaction) & 295.69 & 1 & 295.69 & 6.07 & \\
\hline Between groups & 1257.69 & 3 & 419.23 & & \\
\hline Within groups & 2336.62 & 48 & 48.68 & & \\
\hline Total & 3594.31 & 51 & & & \\
\hline
\end{tabular}


Table 4. The Results of Mean Scores

\begin{tabular}{cccc}
\hline \multirow{2}{*}{ Self-Esteem (B) } & \multicolumn{2}{c}{ Strategies (A) } & Total \\
\cline { 2 - 3 } & PLEASE Strategy (A1) & RAFT Strategy (A2) & Average \\
\hline High Self-Esteem (B1) & 78.92 & 69.62 & 74.27 \\
Low Self-Esteem (B2) & 66.85 & 67.08 & 66.96 \\
\hline Total Average & 72.88 & 68.35 & 70.62 \\
\hline
\end{tabular}

Drawing on the results of ANOVA 2 × 2 test, it can be inferred that:

Firstly, the score of $F_{o}$ between columns (strategies) is 5.50 while the score of $F_{t}$ at the significance level $\alpha=0.05$ is 4.04 . The difference between columns is significant since $F_{o}$ is higher than $\mathrm{F}_{\mathrm{t}}$ or $\mathrm{F}_{\mathrm{o}}>\mathrm{F}_{\mathrm{t}}$. As results, $\mathrm{H}_{0}$ which means there is no difference between PLEASE strategy and RAFT strategy is rejected. It means that PLEASE strategy is significantly different from RAFT strategy. The writing mean score of the students in the experimental class (72.88) is also higher than that of the students in the control class (68.35). It means that PLEASE strategy is more effective than RAFT strategy.

Secondly, the score of $F_{o}$ between rows (self-esteem) is 14.26 while the score of $F_{t}$ at the significance level $\alpha=0.05$ is 4.04 . The difference between rows is significant since $F_{o}$ is higher than $\mathrm{F}_{\mathrm{t}}$ or $\mathrm{F}_{\mathrm{o}}>\mathrm{F}_{\mathrm{t}}$. As results, $\mathrm{H}_{0}$ which means there is no difference between students having high selfesteem and those having low self-esteem is rejected. It means that the students having high selfesteem are significantly different from those having low self-esteem. The writing mean score of the students having high self-esteem (74.27) is also higher than that of the students having low selfesteem (66.96). It means that the students having high self-esteem are better in writing than those having low self-esteem.

Lastly, he score of $F_{\text {interaction }}(6.07)$ is higher than $F_{t}$ (4.04). The difference columns by rows is significant since $F_{\text {interaction }}$ is higher than $F_{t}$ or $F_{\text {interaction }}>F_{t}$. As results, $H_{0}$ which means there is no interaction between employed strategies for writing and students' self-esteem is rejected. It means that there is an interaction between two variables, namely strategies and self-esteem. In other words, the effect of the strategies depends on the degree of the students' self-esteem.

The results of ANOVA $2 \times 2$ test indicate that there are effects and interaction between strategies and self-esteem toward writing. As results, it needs to compare the mean of each group to other means using Tukey test to find out the means which significantly differ from the others. The results of Tukey test are presented in table 5.

Table 5. The Results of Tukey Test

\begin{tabular}{cllrrrrl}
\hline No. & \multicolumn{1}{c}{ Data } & Sample & qo & qt & $\alpha$ & Meaning & \multicolumn{1}{c}{ Status } \\
\hline 1 & A1 and A2 & 26 & 3.32 & 2.91 & 0.05 & qo $>$ qt & Significant \\
2 & B1 and B2 & 26 & 5.34 & 2.91 & 0.05 & qo $>$ qt & Significant \\
3 & A1B1 and A2B1 & 13 & 4.81 & 3.06 & 0.05 & qo $>$ qt & Significant \\
4 & A1B2 and A2B2 & 13 & 0.12 & 3.06 & 0.05 & qo $<$ qt & Not Significant
\end{tabular}

Drawing on the results of Tukey Test, it can be inferred that:

Firstly, writing using PLEASE strategy is significantly different from that of using RAFT strategy since $\mathrm{q}_{\mathrm{o}}$ between columns (3.32) is higher than $\mathrm{q}_{\mathrm{t}}$ at the significance level $\alpha=0.05$ (2.91). The writing mean score of the students using PLEASE strategy (72.88) is higher than that of the students using 
RAFT strategy (68.35). It can be inferred that PLEASE strategy is more effective than RAFT strategy for writing.

Secondly, the students having high self-esteem are significantly different from those having low self-esteem since $\mathrm{q}_{\mathrm{o}}$ between rows (5.34) is higher than $\mathrm{q}_{t}$ at the significance level $\alpha=0.05$ (2.91). The writing mean score of the students having high self-esteem (74.27) is higher than that of the students having low self-esteem (66.96). It can be inferred that the students having high self-esteem are better in writing than those having low self-esteem.

Thirdly, PLEASE strategy is significantly different from RAFT strategy for the students having high self-esteem since $q_{o}$ between cells $A_{1} B_{1}$ and $A_{2} B_{1}$ (4.81) is higher than $q_{t}$ at the significance level $\alpha=0.05$ (3.06). The mean score of $A_{1} B_{1}$ (78.92) is higher than that of $A_{2} B_{1}(69.62)$. It can be inferred that PLEASE strategy is more effective than RAFT strategy for the students having high self-esteem.

Lastly, PLEASE strategy is not significantly different from RAFT strategy for the students having low self-esteem since $q_{o}$ between cells $A_{1} B_{2}$ and $A_{2} B_{2}(0.12)$ is lower than $q_{t}$ at the significance level $\alpha=0.05$ (3.06). The mean score of $A_{1} B_{2}$ (66.85) is lower than that of $A_{2} B_{2}$ (67.08). It can be inferred that RAFT strategy is more effective than PLEASE strategy for the students having low selfesteem.

\section{DISCUSSION}

\section{The Difference between PLEASE Strategy and RAFT Strategy}

The results show that there is a significant difference between PLEASE strategy and RAFT strategy. PLEASE strategy is found to be more effective than RAFT strategy for writing since the mean score of the students using PLEASE strategy is higher than that of the students using RAFT strategy. It can be inferred that PLEASE strategy is more effective than RAFT strategy for writing.

PLEASE strategy is very helpful to deal with particular types of writing problems in prewriting planning, composition, and paragraph revision. It works as a metacognitive problem solver. The students are equipped with a set of behaviors by utilizing a first-letter mnemonic to guide them in accomplishing a writing task independently (Welch, 1992). Moreover, Milford and Milford \& Harrison (2010, pp. 330-332) reveal that PLEASE strategy is useful for students to maintain their ideas on a topic sentence. It can be employed to enhance students' writing and monitor their writing development and writing process. PLEASE strategy is also effective to develop students' metacognitive knowledge in composing paragraphs (Welch, 1992). Further, it can effectively foster the writing of inefficient learners (Welch \& Jensen, 1990).

RAFT strategy facilitates students through writing experience to understand their role as a writer, their audiences, the format of their writing, and the topic being addressed before they start writing (Santa et al., 1988; Sejnost \& Thiese, 2010). Moreover, RAFT strategy demands a teacher to model it first before his students begin to use it independently. It needs long process to make the students familiar with the way to use this strategy. The teacher needs to assign all students the same role, audience, format, and topic for their writing until they are familiar with the way to use this strategy (Sejnost \& Thiese, 2010). It is obvious that PLEASE strategy gives more advantages to the students rather than RAFT strategy.

\section{The Difference between Students Having High Self-Esteem and Students Having Low Self-Esteem}

Problems and failures are better coped by people having high self-esteem. Their equilibrium can be quickly recovered rather than that of people having low self-esteem. People having high selfesteem are good in determining informed decisions. They are eager to try new things, learn from mistakes, and increase their confidence to deal with the next challenges. They are able to develop 
their particular strengths and encounter changes well. They can enjoy life and build successful relationships than those having low self-esteem (Plummer, 2005).

People having high self-esteem are firm and supple to manage their lives and learn from mistakes without any fear of rejection. High self-esteem can be recognized from several signs like optimism, good self-care, non-blaming behavior, et cetera (Soureshjani \& Naseri, 2011). People having high self-esteem are confident in society and school environment. They can keep their learning curiosity. They feel happy and enthusiastic to face new challenges (Lawrence, 2006). They are also more persistent to cope with challenges. High self-esteem seeks challenging and stimulating events (Branden, 1995).

People having high self-esteem typically perform a positive degree of competence and worthiness (Mruk, 2006). High self-esteem functions as positive feelings which are useful in several situations. It also leads to greater initiatives. People having high self-esteem commonly initiate interactions and relationships. They are brave to speak up in a group (Baumeister, Campbell, Krueger, \& Vohs, 2003). In addition, they feel appropriate to life, confident, competent, and worth (Branden, 1995).

In contrast, people having low self-esteem are troublesome to make relationships. Low selfesteem causes anxiety and confusion resulting in an impertinent viewpoint of self and others. People having low self-esteem are typically passive. However, they are aggressive to protect themselves from onset or rejection. They are difficult to set goals and solve problems. They are not confident. They are not willing to try new things because of their fear of failures. Their abilities are underrated. Their achievement is frequently refuted. As results, they cannot do their best in academic and social environments (Plummer, 2005).

People having low self-esteem do not believe in their abilities to be successful. They probably try to prevent humiliating situations (Lawrence, 2006). They require lots of attention (Luxmoore, 2008). They also tend to give up or try without doing their best. Low self-esteem seeks familiar events for safety (Branden, 1995). It leads to lacks of competence and worthiness (Mruk, 2006). Low self-esteem can be recognized from several syndromes such as negative view of life, fear of being ridiculed, fear of taking any risk, et cetera (Soureshjani \& Naseri, 2011).

Affective variables or attitudes truly affect students' writing (Alluhaybi, 2015). It has been revealed that there is a positive relationship between students' self-esteem and their writing (Fahim \& Rad, 2012; Khansir \& Abdolahi, 2014). Therefore, the difference between the students having high self-esteem and those having low self-esteem suggests that the students having high self-esteem are better in writing than those having low self-esteem.

\section{The Interaction between Strategies and Students' Self-Esteem}

The difference between PLEASE strategy and RAFT strategy for writing has been discussed leading to several insights. PLEASE strategy is more effective than RAFT strategy and gives more advantages to the students rather than RAFT strategy. However, there are two groups of students namely the students having high self-esteem and the students having low self-esteem. These two groups of students are also different as their difference has also been discussed. This difference affects their learning behaviors and results. It implies that an effective strategy may have different results when it is used by different groups of students.

In lights of the characteristics of the students having high self-esteem and the students having low self-esteem as well as their writing mean scores, PLEASE strategy is more impactful and effective when it is used by the students having high self-esteem. PLEASE strategy is more effective than RAFT strategy for the students having high self-esteem. In contrast, PLEASE strategy is not significantly different from RAFT strategy when it is used by the students having low self-esteem. 
RAFT strategy is even more effective than PLEASE strategy for the students having low self-esteem. It can be inferred that there is an interaction between the strategies and the students' self-esteem.

\section{CONCLUSION}

Drawing on the research results, it can be concluded that: (1) PLEASE strategy is more effective than RAFT strategy for writing; (2) Students having high self-esteem are better in writing than those having low self-esteem; and (3) There is an interaction between the strategies and the students' self-esteem. However, this research has some limitations. It does not investigate classroom situations when PLEASE strategy is employed. It merely gathers and analyzes quantitative data. Moreover, it does not use pre-test on the students' writing. It also does not utilize media, except PowerPoint presentation, white board, and handout.

Further researches employing qualitative data to investigate classroom situations are encouraged. It is also suggested to seek students' perceptions on the use of PLEASE strategy and teachers' belief on PLEASE strategy. Moreover, classroom action research is welcome to discover how much each indicator of students' writing develop through some cycles. Researches incorporating PLEASE strategy with innovative media and materials are encouraged too. Different attributive variables can also be interesting to be investigated.

\section{REFERENCES}

Adler-Kassner, L., \& O’Neill, P. (2010). Reframing writing assessment to improve teaching and learning. Utah: Utah State University Press.

Akincilar, V. (2010). The effect of "PLEASE" strategy training through the self-regulated strategy development (SRSD) model on fifth grade EFL students' descriptive writing: Strategy training on planning. Ankara: Unpublished Thesis.

Alluhaybi, M. (2015). Psychology and EFL writing. Procedia-Social and Behavioral Sciences, 192, 371378.

Baumeister, R. F., Campbell, J. D., Krueger, J. I., \& Vohs, K. D. (2003). Does high self-esteem cause better performance, interpersonal success, happiness, or healthier lifestyles? Psychological Science in the Public Interest, 4(1), 1-44.

Branden, N. (1995). The six pillars of self-esteem. New York: Bantam Books.

Brown, H. D. (2001). Teaching by principles: An interactive approach to language pedagogy (1st ed.). New York: Longman.

Browne, A. (2007). Teaching and learning communication, language and literacy. London: Paul Chapman Publishing.

Byrne, D. (1993). Teaching writing skills (New Edition). London: Longman.

Caunt, J. (2003). Boost your self-esteem. London: Kogan Page Limited.

Davison, J., \& Dowson, J. (2002). Learning to teach English in the secondary school: A companion to school experience. London: Routledge.

Fahim, M., \& Rad, S. K. (2012). The relationship between self-esteem and paragraph writing of Iranian EFL learners. Psychology, 3(01), 24.

Flynn, N., \& Stainthorp, R. (2006). The learning and teaching of reading and writing. West Sussex: John Wiley \& Sons Ltd. 
Greene, I. (2003). How to improve self-esteem in the African American child. San Diego: P. S. I. Publishers.

Guzel-Ozmen, R. (2009). Modified cognitive strategy instruction: An expository writing strategy. Intervention in School and Clinic, 44(4), 216-222.

Hyland, K. (2009). Teaching and researching writing (2nd ed.). Harlow: Pearson Education Limited.

Ka-kan-dee, M., \& Kaur, S. (2015). Teaching strategies used by Thai EFL lecturers to teach argumentative writing. Procedia-Social and Behavioral Sciences, 208, 143-156.

Khansir, A. A., \& Abdolahi, Z. (2014). Self-esteem and writing achievements of Iranian EFL learners. International Journal of English Language and Literature Studies, 3(2), 155-164.

Koutsoubou, M. (2005). Deaf ways of writing narratives: a bilingual approach. In Effective Learning and Teaching of Writing (pp. 151-167). Springer.

Lawrence, D. (2006). Enhancing self-esteem in the classroom (3rd ed.). London: Paul Chapman Publishing.

Luxmoore, N. (2008). Feeling like crap: Young people and the meaning of self-esteem. Philadelphia: Jessica Kingsley Publishers.

Milford, T., \& Harrison, G. L. (2010). Using the PLEASE strategy with a struggling middle school writer with a disability. Intervention in School and Clinic, 45(5), 326-332.

Mruk, C. J. (2006). Self-esteem research, theory, and practice: Toward a positive psychology of selfesteem (3rd ed.). New York: Springer Publishing Company, Inc.

Nation, I. S. P. (2009). Teaching ESL/EFL reading and writing. New York: Routledge.

Nielsen, K. (2012). Self-assessment methods in writing instruction: A conceptual framework, successful practices and essential strategies. Journal of Research in Reading, 37(1), 1-16.

Nik, Y. A., Hamzah, A., \& Rafidee, H. (2010). A comparative study on the factors affecting the writing performance among bachelor students. International Journal of Educational Research and Technology, 1(1), 54-59.

Plummer, D. (2005). Helping adolescents and adults to build self-esteem: A photocopiable resource book. London: Jessica Kingsley Publishers.

Puteh, S. N., Rahamat, R., \& Karim, A. A. (2010). Writing in the second language: Support and help needed by the low achievers. Procedia-Social and Behavioral Sciences, 7, 580-587.

Rijlaarsdam, G., Bergh, H. Van Den, \& Couzijn, M. (2005). Effective learning and teaching of writing. In Effective learning and teaching of writing (pp. 1-16). Springer.

Santa, C. M., Havens, L., Nelson, M., Danner, M., Scalf, L., \& Scalf, J. (1988). Content reading including study systems: Reading, writing and studying across the curriculum. Iowa: Kendall/Hunt Publishing Company.

Sejnost, R. L., \& Thiese, S. M. (2010). Building content literacy: Strategies for the adolescent learner. California: Corwin.

Soureshjani, K. H., \& Naseri, N. (2011). An investigation into the relationship between self-esteem, proficiency level, and the reading ability of Iranian EFL language learners. Journal of Language Teaching and Research, 2(6), 1312. 
Welch, M. (1992). The PLEASE strategy: A metacognitive learning strategy for improving the paragraph writing of students with mild learning disabilities. Learning Disability Quarterly, 15(2), 119-128.

Welch, M., \& Jensen, J. B. (1990). Write, PLEASE: A video-assisted strategic intervention to improve written expression of inefficient learners. Remedial and Special Education, 12(1), 37-47.

Yerger, W. (2014). Three dynamic approaches to create successful writers. International Journal of Languages and Literatures, 2(1), 1-19. 